SCIREA Journal of Geosciences

http://www.scirea.org/journal/Geosciences

May 22, 2021

Volume 5, Issue 1, February 2021

\title{
Removal, Recovery, and Recycles of Gold (III) from Aqueous Gold (III) Solution Using Immobilized Pseudomonas saccharophila Cells by Biomineralization and Thiourea Oxidation
}

\author{
Takehiko Tsuruta ${ }^{1,2^{*}}$, Yuki Odajima1, Kato Marina ${ }^{1}$, Ichiro Maeda ${ }^{2}$ \\ ${ }^{1}$ Department of Life and Environmental Science, Hachinohe Institute of Technology, \\ Hachinohe, Japan \\ ${ }^{2}$ Department of Mechanical and Biochemical Engineering, Graduate School of Hachinohe \\ Institute of Technology, Hachinohe, Japan \\ *Corresponding author: tsuruta@hi-tech.ac.jp
}

\begin{abstract}
Recently, some researchers have investigated the recovery of gold using microbial cells, such as bacteria, fungi, yeasts, and algae. However, there is little information on which kind of microorganisms has a high gold adsorbing ability. We have reported various species and strains of bacteria, actinomycetes, fungi, and yeasts were screened for their ability to adsorb gold from a solution containing hydrogen tetrachloroaurate (III). Hydrogen tetrachloroaurate (III) is used for medical and ceramic materials. The effect of $\mathrm{pH}$, external gold concentration, cell amounts on gold biosorption, and the time course of gold biosorption by Pseudomonas maltophilia cells, which adsorbed large amounts of gold from a solution containing hydrogen tetrachloroaurate (III), were reported in detail. In this chapter, in order to approve the amount of gold recovery much higher, the removal of gold (III) by biosorption and biominaralization from aqueous
\end{abstract}


systems using microbial cells, gold (III) removal by those using microbial cells was investigated.Additionally,the oxidative recovery of gold after reduced gold(0) by the oxidation using aqueous thiourea solution, and recycles of gold reduction-oxidation cycles.

Keywords: gold (III) biosorption, gold (0) biomineralization, microorganism, Peudomonas $\underline{\text { saccharophila, thiourea, recycles }}$

\section{Introduction}

The demand for gold has significantly increased because of its increasing use in the electrical industry and the development of gold-containing drugs [1]. Therefore, recycling this valuable resource has become a subject of great interest.

Several researchers have investigated gold recovery using microbial cells, such as bacteria [2], fungi [3-5], yeasts [6], and algae [7, 8]. However, there is little information on the species of microorganisms that have a high gold adsorbing ability.

We previously reported that several microorganisms adsorb gold, and screened resting 75 microbial strains (19 actinomycetes, 25 bacteria, 17 fungi, and 14 yeasts) from a hydrogen tetrachloroaurate (III)-containing solution [9]. Hydrogen tetrachloroaurate (III) is used for medical and ceramic materials. Of the tested microorganisms, some gram-negative bacteria showed gold-adsorption ability. These microorganisms adsorbed over 330 mol gold per gram of microbial cells (dry wt.) from the solution containing hydrogen tetrachloroaurate (III) within $1 \mathrm{~h}$. The gold adsorbed from hydrogen tetrachloroaurate (III) solution by gramnegative bacteria was higher than that adsorbed by gram-positive bacteria, actinomycetes, fungi, and yeasts. These results are in contrast to those reported for the adsorption of the amount of lithium [10], cadmium [11], uranium [12], thorium [13], and rare earth metals [14], these were adsorbed in higher amounts by gram-positive bacteria compared to the gramnegative bacteria, fungi, and yeasts. The results show that gram-positive bacteria can adsorb a large amount of positively -charged metal ions, while gram-negative bacteria can adsorb a large amount of negatively -charged complex ions [9-14]. Gold (III) exists as a negatively charged-complex ion in acidic solution. The negative charge of the gram-positive bacterial cell surface is higher than that of the gram-negative bacteria, because teichoic acid levels are higher in the former at a neutral $\mathrm{pH}$ [15-17]. In other words, the positive charge of the gram- 
negative bacterial cell surface is higher than that of the gram-positive bacterial cell surface. Accordingly, negatively -charged gold complex ions bond more strongly on the positively charged gram-negative bacterial cell surface [9].

We investigated the effects of $\mathrm{pH}$, external gold concentration, cell amount, and gold contact time in Pseudomonas maltophilia, which adsorbs large amounts of gold from a hydrogen tetrachloroaurate (III) containing solution [9].

In this study, the investigation was performed to improve gold removal by biosorption and biomineralization from aqueous systems using microbial cells. Additionally, in order to develop a practical approach, the determination of a suitable desorbent for gold adsorbed by immobilized P. maltophilia cells and biosorption-desorption cycles was also presented [9]. In order to approve the amount of gold recovery much higher, the removal of gold (III) by biosorption and biominaralization from aqueous systems using microbial cells, gold (III) removal and recovery recycles using immobilized microbial cells was reported in this paper.

\section{Material and Methods}

\section{Culture of Microorganisms}

Your paper must use a page size corresponding to A4 which is $210 \mathrm{~mm}$ wide and $297 \mathrm{~mm}$ long. The margins are set as follows: top $=15 \mathrm{~mm}$, bottom $=15 \mathrm{~mm}$, right $=17.5 \mathrm{~mm}$, left $=20 \mathrm{~mm}$. Your paper must be in two column format with a space of 1.93 characters between columns.

The strains used in this research were generously donated by the IAM Culture Collection, Center for Cellular and Molecular Research, the Institute of Molecular and Cellular Biosciences, the University of Tokyo (IAM), the Faculty of Engineering, Hiroshima University (HUT), and the Faculty of Agriculture, Hokkaido University (AHU). All chemicals (guaranteed reagents) used in this study were obtained from Nacalai Tesque (Kyoto, Japan).

The bacterial culture medium contained $3 \mathrm{~g} / \mathrm{L}$ meat extract, $5 \mathrm{~g} / \mathrm{L}$ peptone, and $5 \mathrm{~g} / \mathrm{L} \mathrm{NaCl}$ in deionized water. The medium for growing actinomycetes, fungi, and yeasts contained $4 \mathrm{~g} / \mathrm{L}$ yeast extract, $10 \mathrm{~g} / \mathrm{L}$ malt extract, and $4 \mathrm{~g} / \mathrm{L}$ glucose in deionized water with $\mathrm{pH} 7.1$ (for actinomycetes) and $\mathrm{pH} 5.7$ (for fungi and yeasts). The microorganisms were maintained on agar slants and grown in $300 \mathrm{~mL}$ of the medium in a $500-\mathrm{mL}$ flask with continuous shaking (120 rpm) for $72 \mathrm{~h}$ at $30{ }^{\circ} \mathrm{C}$. Cells were collected by centrifugation (for bacteria and yeasts) or 
by filtration through a filter paper (for actinomycetes and fungi), which is washed thoroughly with deionized water, and then used in gold removal experiments.

\section{Gold (III) Removal Experiment}

Unless otherwise stated, the removal experiments were conducted as follows. Resting microbial cells [15 mg dry weight basis for tetrachloroaurate (III)] were suspended in $100 \mathrm{~mL}$ solution containing $50 \mathrm{mg} / \mathrm{L}(254 \quad \mathrm{M})$ gold ( $\mathrm{pH} \mathrm{3.0)}$ containing hydrogen tetrachloroaurate (III). The suspension was shaken for $72 \mathrm{~h}$ at $30{ }^{\circ} \mathrm{C}$. The resting microbial cells were then removed by filtration through a membrane filter $(0.2 \mathrm{~m}$ pore size $)$. The gold removed by the cells was determined by measuring the gold content in the filtrate with an atomic absorption analysis quantometer (AA-6300, Shimadzu Corporation, Kyoto, Japan).

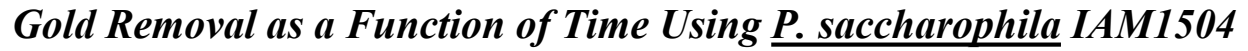

The title should be formatted in an hourglass style; the first line longer than the second, the second line shorter than the third. Use numerical superscript callouts as shown in this template to link authors with their affiliations. Corresponding author should be denoted with an asterisk as shown. Email address is compulsory for the corresponding author.

Resting cells (15 mg on a dry wt. basis) were suspended in $100 \mathrm{~mL}$ solution (pH 3.0) containing hydrogen tetrachloroaurate (III) (254 M, pH 3.0) for tenures varying from $5 \mathrm{~min}$ to $68 \mathrm{~h}$ at $30{ }^{\circ} \mathrm{C}$.

\section{Effect of pH on Gold (III) Removal Using P. saccharophila IAM1504}

Resting cells (15 mg on a dry wt. basis) were suspended in a $100 \mathrm{~mL}$ solution ( $\mathrm{pH}$ from1 to 5) containing hydrogen tetrachloroaurate (III) $\left(254\right.$ M) for 1 or $72 \mathrm{~h}$ at $30^{\circ} \mathrm{C}$.

\section{Effect of Cell Amount on Gold (III) Removal Using P. saccharophila IAM1504}

Resting cells (from 5 to $23 \mathrm{mg}$ on a dry wt. basis) were suspended in a $100 \mathrm{~mL}$ solution (pH 4.0) containing hydrogen tetrachloroaurate (III) $(254 \quad \mathrm{M})$ for $1 \mathrm{~h}$ or $72 \mathrm{~h}$ at $30{ }^{\circ} \mathrm{C}$.

\section{Effect of Gold (III) Concentration on Gold (III) Removal Using P. saccharophila IAM1504}

Resting cells (15 mg on a dry wt. basis) were suspended in a $100 \mathrm{~mL}$ solution ( $\mathrm{pH} 3.0$ ) containing $0 \mathrm{mg} / \mathrm{L}, 50 \mathrm{mg} / \mathrm{L}, 100 \mathrm{mg} / \mathrm{L}, 150 \mathrm{mg} / \mathrm{L}, 200 \mathrm{mg} / \mathrm{L}$, or $250 \mathrm{mg} / \mathrm{L}$ gold(III) as hydrogen tetrachloroaurate (III) (pH 4.0) for $1 \mathrm{~h}$ or $72 \mathrm{~h}$ at $30^{\circ} \mathrm{C}$.

\section{Immobilization of $\underline{P . \text { saccharophila IAM1504 }}$}


Precultured $P$. saccharophila cells (5.0 g fresh weight) were suspended in $4.5 \mathrm{ml}$ isotonic sodium chloride solution and $680 \mathrm{mg}$ acrylamide monomer, $34 \mathrm{mg} \mathrm{N}$, N'-methlenebis(acrylamide), $\quad 0.30 \mathrm{ml}$ 3-dimethylaminopropionitrile solution $(5.0 \%)$, and $0.34 \mathrm{ml}$ potassium persulfate solution (2.5\%) were added to the suspension. After solidification, the gel was crushed into small pieces (50-100 mesh), washed thoroughly with isotonic sodium chloride solution followed by deionized water, and then used in the following gold removal experiments.

\section{Reductive Gold Removal Using Immobilized P. saccharophila IAM1504}

Figure captions should be below the figures. Figures must be numbered using Arabic numerals. Figure captions must be in 8 pt Regular font. Captions of a single line (e.g. Figure 2) must be centered whereas multi-line captions must be justified (e.g. Figure 1). Captions with figure numbers must be placed after their associated figures, as shown in Figure 1.

Immoblized microbial cells (15 mg dry wt. microbial cell basis) were suspended in $100 \mathrm{ml}$ of $50 \mathrm{mg} / \mathrm{L}(254 \mathrm{mM})$ of gold solution ( $\mathrm{pH} 3.5)$ containing hydrogen tetrachloroaurate (III), and the suspension was shaken for $72 \mathrm{~h}$ at room temperature. The immobilized microbial cells were then removed by filtration through a membrane filter (pore size $0.2 \mathrm{~mm}$ ). The amounts of gold removed by the cells were determined by measuring the gold content in the filtrate using an atomic absorption analysis quantometer (AA-6300, Shimadzu Corporation, Kyoto).

Oxidative Recovery from Gold Reduced by Immobilized P. saccharophila IAM1504 Using

\section{Thiourea Solution}

Immoblized microbial cells removed gold was mixed with $100 \mathrm{ml}$ of $0.25 \mathrm{M}$ thiourea solution (pH 3.0) for $17 \mathrm{~h}$ at $30^{\circ} \mathrm{C}$. Treatment after this procedure was same with above mentioned.

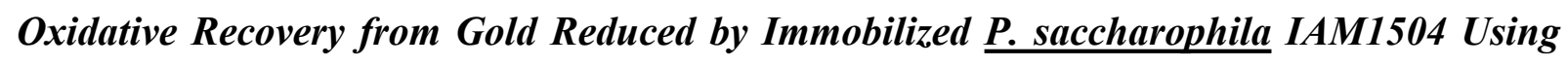
Thiourea Solution

Recycles of Reductive Gold Removal and Oxidative Recovery Using Immobilized $P$. saccharophila IAM1504

Time Course of Oxidative Recovery of Gold from Gold Reduced Immobilized $\underline{P}$. saccharophila IAM1504 Using Thiourea solution

Immoblized microbial cells (15 mg dry wt. microbial cell basis) removed gold was mixed with $100 \mathrm{ml}$ of $0.25 \mathrm{M}$ thiourea solution $(\mathrm{pH} \mathrm{3.0)}$ ) for $0.5-18 \mathrm{~h}$ at room temperature. Treatment after this procedure was same with above mentioned. 
Time Course of Reductive Gold Removal Using Immobilized P. saccharophila IAM1504 at the Second Time

Immoblized microbial cells ( $15 \mathrm{mg}$ dry wt. microbial cell basis) reduced ( $72 \mathrm{~h}$ ) and oxidized

(1h) gold one time was remixed with in $100 \mathrm{ml}$ of $50 \mathrm{mg} / \mathrm{L}(254 \mathrm{mM})$ of gold solution ( $\mathrm{pH} \mathrm{3.5)}$ containing hydrogen tetrachloroaurate (III) for $0.5-18 \mathrm{~h}$ at room temperature. Treatment after this procedure was same with above mentioned.

Time Course of Reductive Gold Removal Using Immobilized P. saccharophila IAM1504 at the Second Time

Above mentioned Reductive removal (for the first time $72 \mathrm{~h}$ and after second time $1 \mathrm{~h}$, and oxidative recovery of gold for $1 \mathrm{~h}$ were recycled 5 times.

\section{Results and Discussion}

Gold Removal as a Function of Time Using P. saccarophila IAM1504

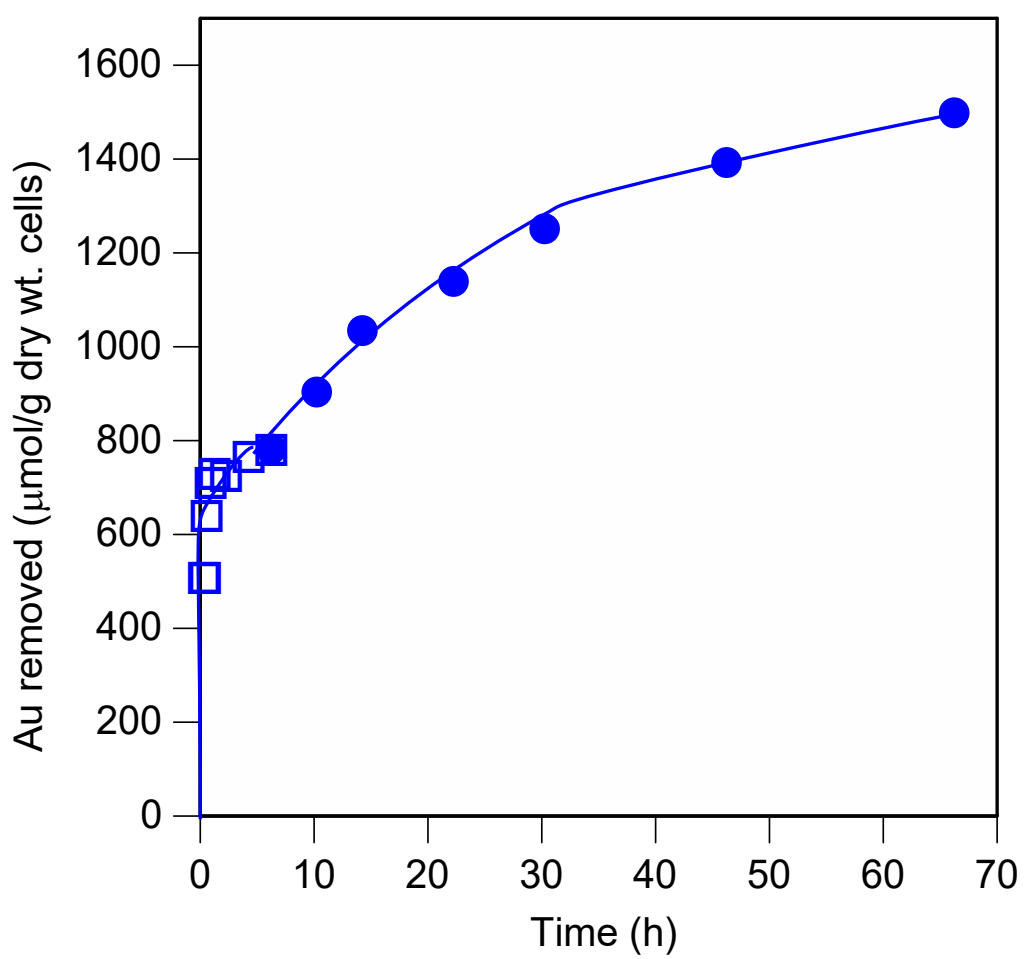

Figure 1. Gold (III) removed by $P$. saccharophila cells. With the passage of time. Squares: within $6 \mathrm{~h}$ (biosorption), circles: contact for $>6 \mathrm{~h}$ (biomineralization). 
Gold (III) removal as a function of time using $P$. saccharophila IAM1504 was examined (Figure 1); the amount of gold removed increased with incubation time. Importantly, gold removal reached two equilibria. The first equilibrium state was at approximately $6 \mathrm{~h}$, and likely occurred by biosorption. Following this, the amount of gold removed increased again, and the solution color became darker, indicating biomineralization. The amount of gold removed using $P$. saccharophila IAM1504 by biosorption was relatively large [9], additionally the amount removed by biomineralization was much larger than biosorption.

\section{Effect of pH on gold (III) Removal from Aqueous gold (III) Using P. saccharophila Cells}

Gold (III) removal by $P$. sacharophila cells was significantly affected by $\mathrm{pH}$ (Figure. 2). The maximum amount of gold removal occurred at $\mathrm{pH} 3.0$ (for $1 \mathrm{~h}$ ) or $\mathrm{pH} 3.5$ (for $72 \mathrm{~h}$ ).

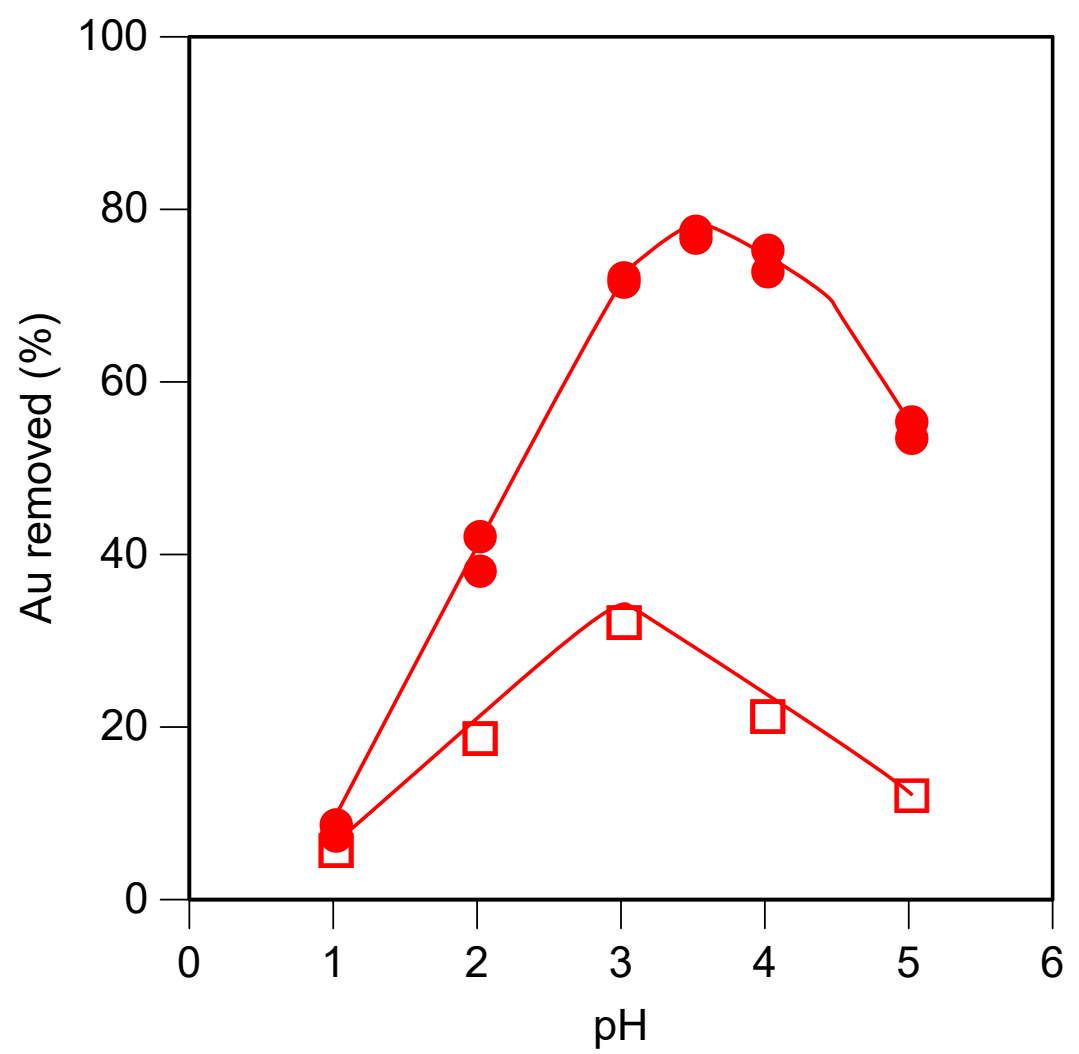

Figure 2. Effect of pH on gold (III) on the removal of gold (III) by $P$. saccharophila cells. Squares: for $1 \mathrm{~h}$ (biosorption), circles: contact for $72 \mathrm{~h}$ (biomineralization).

These results suggest that longer incubation time may change the reaction mechanism responsible for gold removal. The solution was nearly colorless after $1 \mathrm{~h}$. However, the color changed to violet, green during the $72 \mathrm{~h}$ incubation period. Owing to the tetrachloroaurate ion having a negative charge, gold (III) can be effectively removed at $\mathrm{pH} 3$ via biosorption [9]. It 
can also be reduced to atomic gold (0) by the activity of reductase in the presence of NADH [18] via biomineralization. Reduction occurred as shown in the following equation:

$2 \mathrm{Au}^{3+}+3 \mathrm{NADH} \longrightarrow 2 \mathrm{Au}+3 \mathrm{NAD}^{+}+3 \mathrm{H}^{+}$

The equilibrium in an acidic solution is driven to the left; thus, suitable $\mathrm{pH}$ changed from 3.0 to 3.5 .

\section{Effect of Cell Amounts on gold (III) Removal from Aqueous gold (III) Using $P$. saccharophila Cells}

The amount of gold (III) removed ( mol/g dry wt. cells) by P. saccharophila cells decreased slightly with an increase in the cell amount (Figure 3). However, increasing the cell amount of P. saccharophila IAM1504 increased the total gold (III) removal. About $1300 \mathrm{~mol}$ gold/g dry wt. cells were removed using $5.4 \mathrm{mg}$ dry wt. of $P$. saccharophila cells after $72 \mathrm{~h}$ incubation. Although the solution color did not change after $1 \mathrm{~h}$ incubation, the color changed to violet after $72 \mathrm{~h}$.

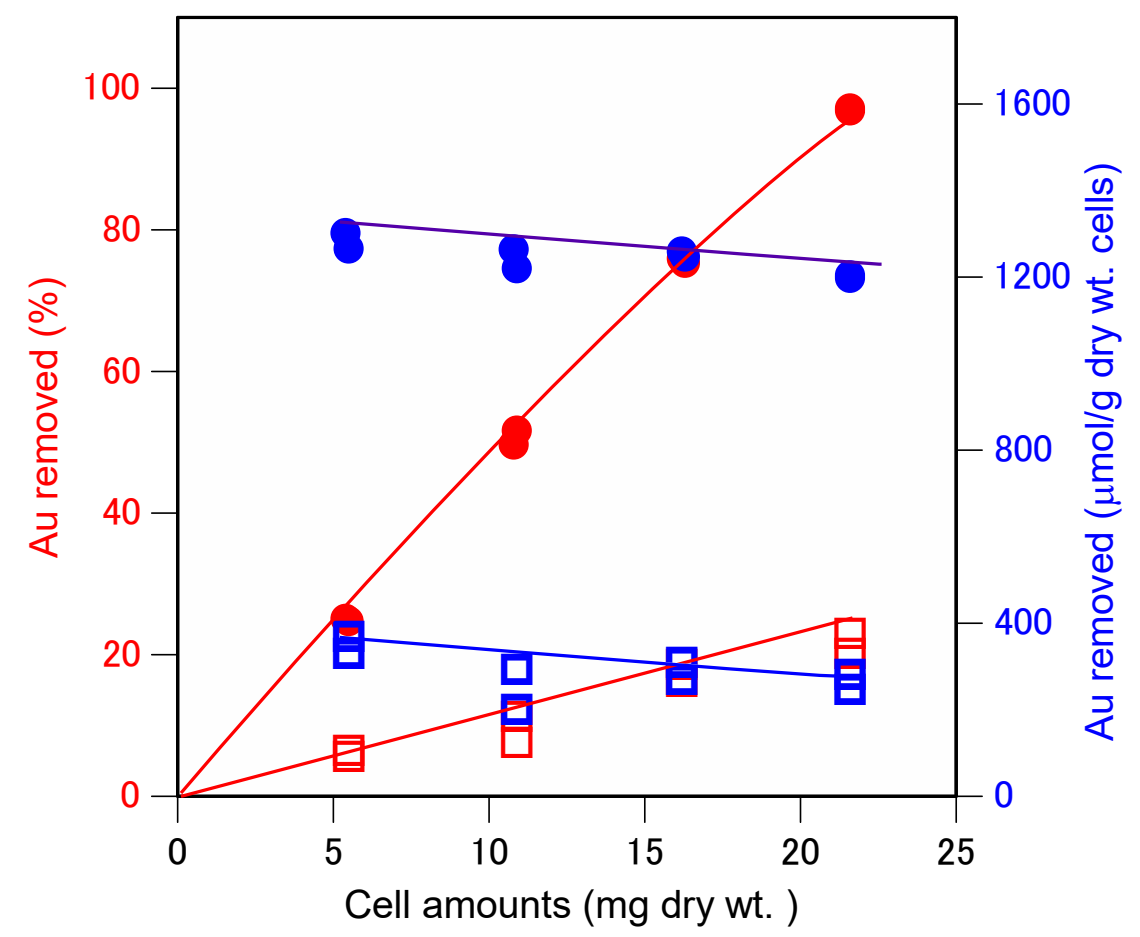

Figure 3. Effect of cell amounts on the removal of gold (III) by $P$. saccharophila cells. Red symbols: gold removed (\%), blue symbols: gold removed ( mol/g dry wt. cells), circles; contact 72 h (biomineralization), squares; 1 h (biosorption). 
Effect of Gold Concentration on gold (III) Removal from Aqueous gold (III) Using $P$. saccharophila Cells

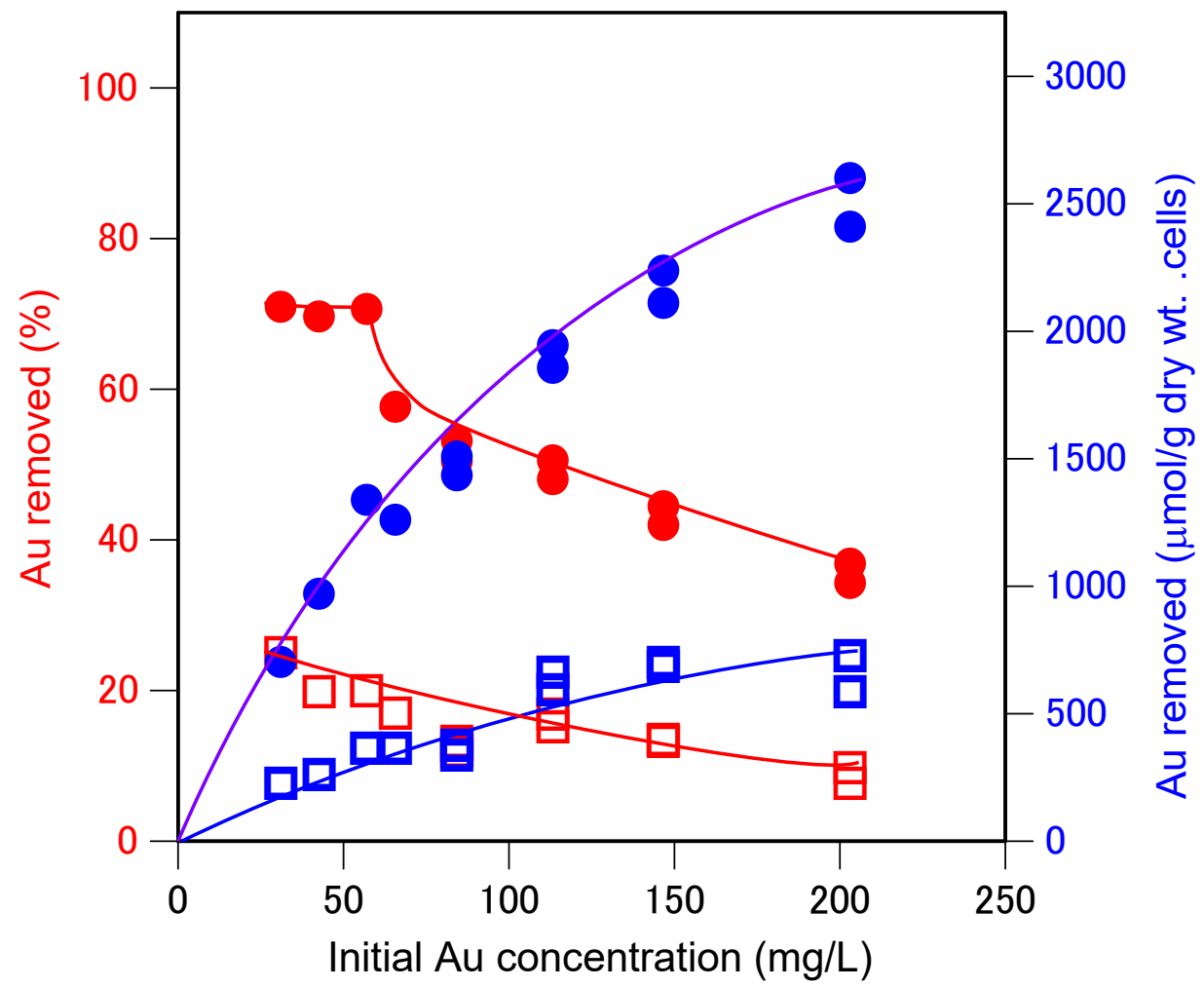

Figure 4. Effect of initial gold concentration on the removal of Au (III) by $P$. saccharophila cells.

Red symbols: Au removed (\%), blue symbols: Au removed ( mol/g dry wt. cells), circle symbols: contact $72 \mathrm{~h}$ (biomineralization), square symbols: $1 \mathrm{~h}$ (biosorption).

To determine the maximum gold (III) removal ability at $\mathrm{pH} 4.0$, we examined the mechanism by which the gold (III) concentration affected the gold removal by P. saccharophila cells. The amount of gold removed ( $\mathrm{mol} / \mathrm{g}$ dry weight cells) by $P$. saccharophila cells increased with increased gold concentration, whereas the ratio of total amount of gold to the gold concentration decreased (Figure 5). For gold (III) concentration of $200 \mathrm{mg} / \mathrm{L}(1,020 \quad \mathrm{M})$, $2500 \mathrm{~mol}$ gold/g dry cell wt. was observed at $\mathrm{pH} 4.0$. 


\section{Recycles of Reductive Gold Removal and Oxidative Recovery Using Immobilized $P$. saccharophila Cells}

Recycles of gold removal by biosorption and recovery by desorption using immobilized $P$. maltophilia cells in column system was reported (Tsuruta, 2004). In this paper, recycles of gold removal by biominaralization and oxidative recovery using immobilized $P$. saccharophila cells by batch system. Removal experiment was proceeded $72 \mathrm{~h}$ because of the reductive removal was proceeded slowly to violet color (Figure 5a) over 72h (Maeda and Tsuruta, 2013). However, after second time, the color of solution was changed to golden color (Figure 5b) rapidly after adding the gold(III) solution. Oxidative recovery was continued one night $(17 \mathrm{~h})$, however, color of cell surface was changed to colorless rapidly after adding thiourea solution. As shown in Figure 6, recycles of removal biomineralization and oxidative removal can be done 5 times.

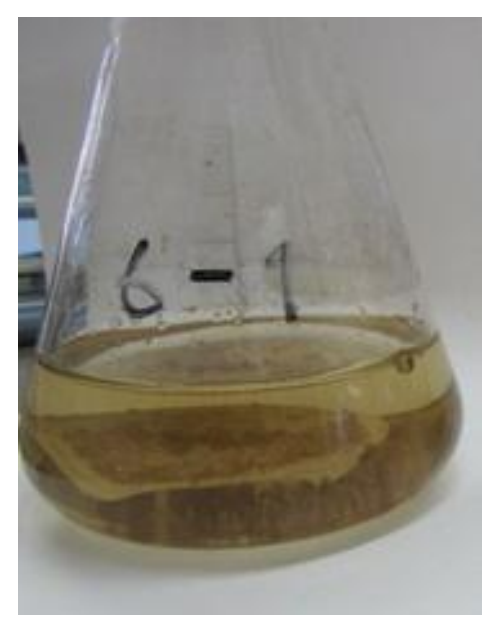

a

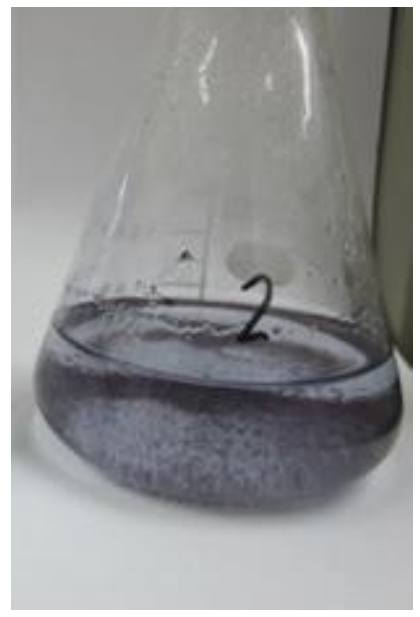

b

Figure 5. Color of the reaction mixture.

a: Immobilixzed $P$. saccharophila cells was mixed with $\mathrm{Au}(\mathrm{III})$ solution after $72 \mathrm{~h}$ (the first time). b: That after 5 min (the second time). 


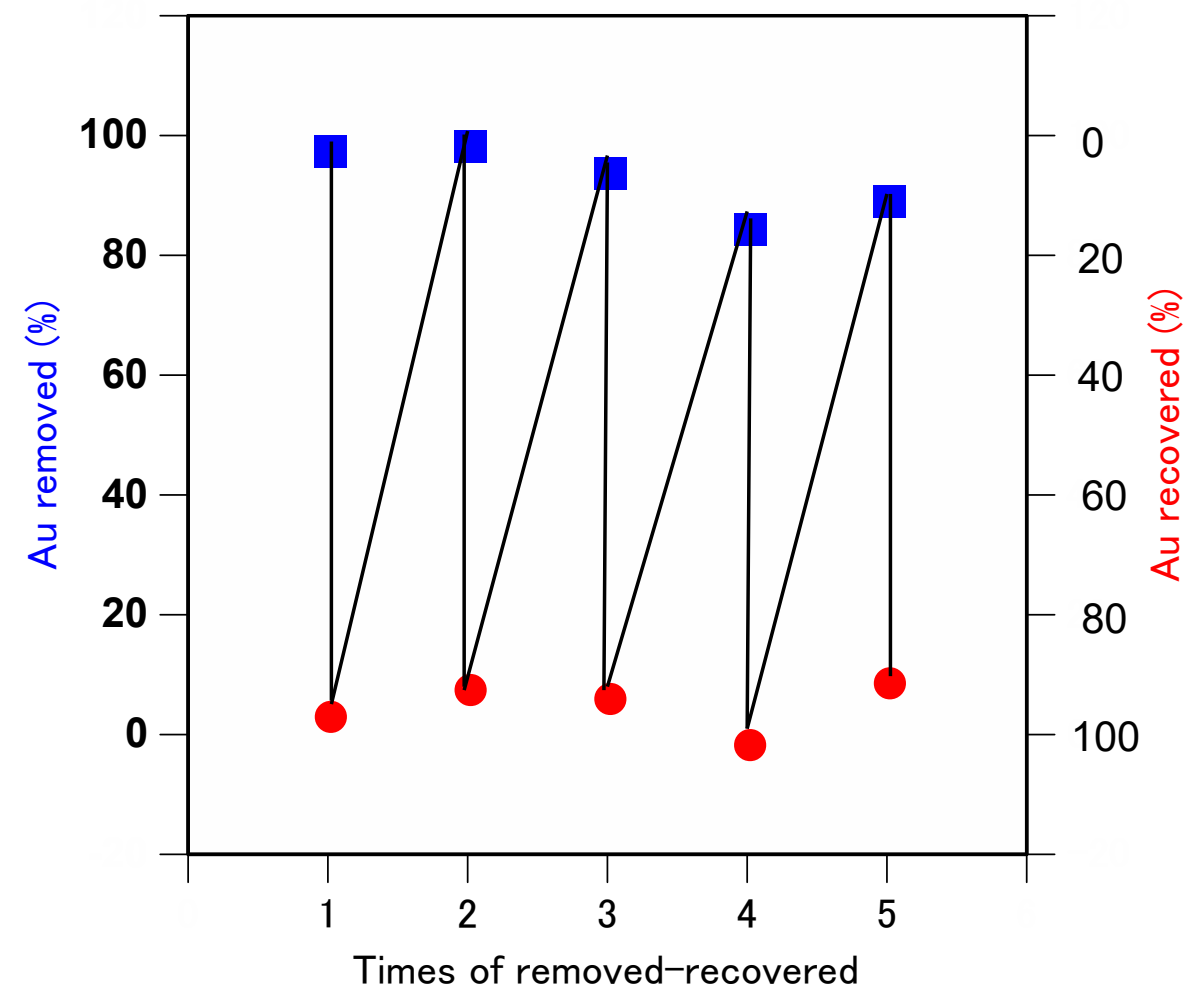

Figure 6. Recycles gold removal (72h) and recovery of gold (17h) by immobilized $P$. saccharophila cells

Time Course of Gold Recovery from the Gold reduced by Immobilized $P$. saccharophila cells Using Thiourea Solution.

From the above mentioned recycled result, the oxidative recovery was proceeded very rapidly. Therefore, time course of gold recovery from the gold reduced by immobilized $P$. saccharophila cells using $100 \mathrm{~mL}$ of $0.25 \mathrm{M}$ thiourea solution was examined from $0.5-15 \mathrm{~h}$. As shown in Fig. 2, oxidation of gold(0) was very rapid and over $90 \%$ of reduced $\mathrm{Au}(0)$ was oxidized and recovered into the solution within $0.5 \mathrm{~h}$. 


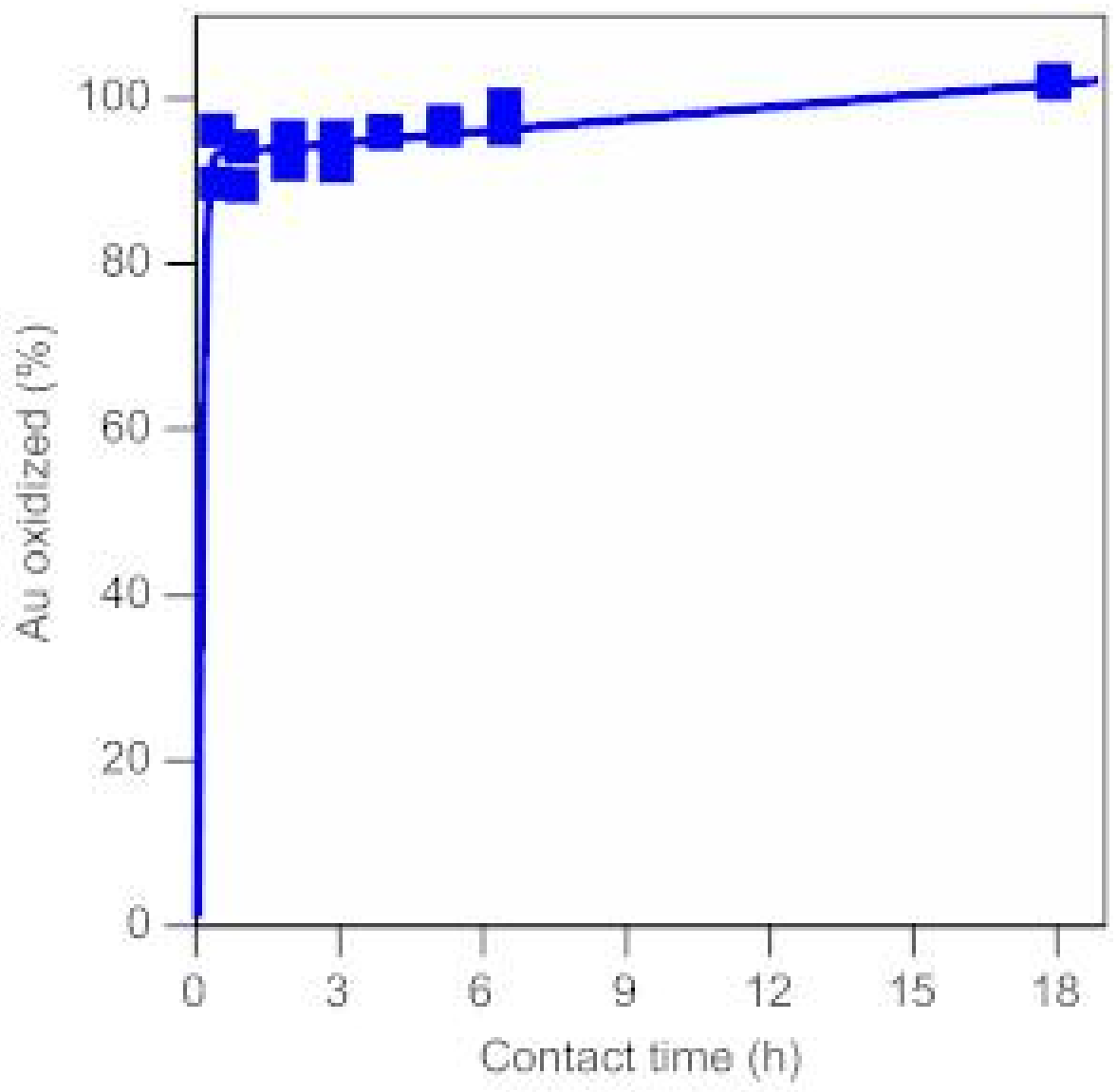

Figure 7. Time course of gold recovery from the gold reduced by immobilized P. saccharophila cells using $100 \mathrm{~mL}$ of $0.25 \mathrm{M}$ thiourea solution.

Time Course of the Second Times Reductive Gold Removal from the Hydrogen Tetrachloroaurate(III) solution Using Immobilized $\boldsymbol{P}$. saccharophila cells Used Once.

As the color of the solution was rapidly changed after adding the gold solution at the second times of the removal of gold from the hydrogen tetrachloroaurate(III) using immobilized $P$. saccharophila cells, time course of second times reductive gold removal from the hydrogen tetrachloroaurate(III) using immobilized P. saccharophila cells was examined. As shown in Figure 8, removal of gold(III) was very rapid and over $90 \%$ of $\mathrm{Au}(\mathrm{III})$ was reduced and removed from the solution within $0.5 \mathrm{~h}$. 


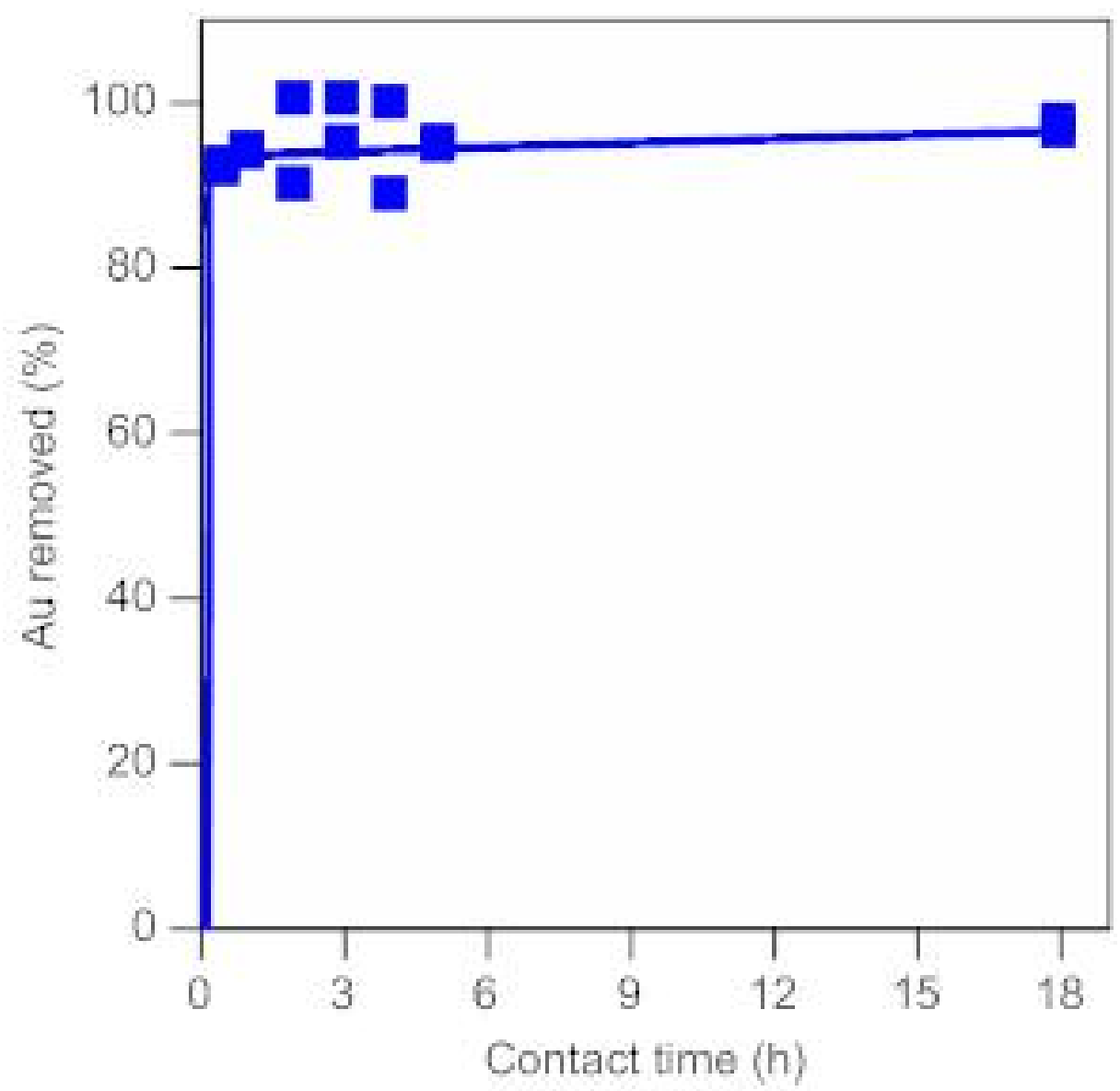

Figure 8. Time course of the gold removal from the hydrogen tetrachloroaurate(III) using by immobilized $P$. saccharophila cells (at second times).

\section{Recycles of Reductive Gold Removal (Improved After Second Times) and Oxidative Recovery Using Immobilized $P$. saccharophila Cells}

Reductive removal of gold was proceeded slowly over $72 \mathrm{~h}$ by immobilized $P$. saccharophira cells at the first time, however, oxidative recover and the reductive removal after second time was rapidly proceeded within $1 \mathrm{~h}$. Therefore, reductive removal of gold using immobilized $P$. saccharophila cells at the first time was done for $72 \mathrm{~h}$, followed recycles of oxidative removal and reductive removal of gold after second times using immobilized $P$. saccharophila cells were done for $1 \mathrm{~h}$ until total five times. As shown in Figure 9, reductive removal and oxidative recovery of gold were done effectively. Therefore, immobilized $P$. saccharophila cells can remove and recover gold from the solution containing high concentaration of hydrogen tetrachloroaurate(III) solution. 


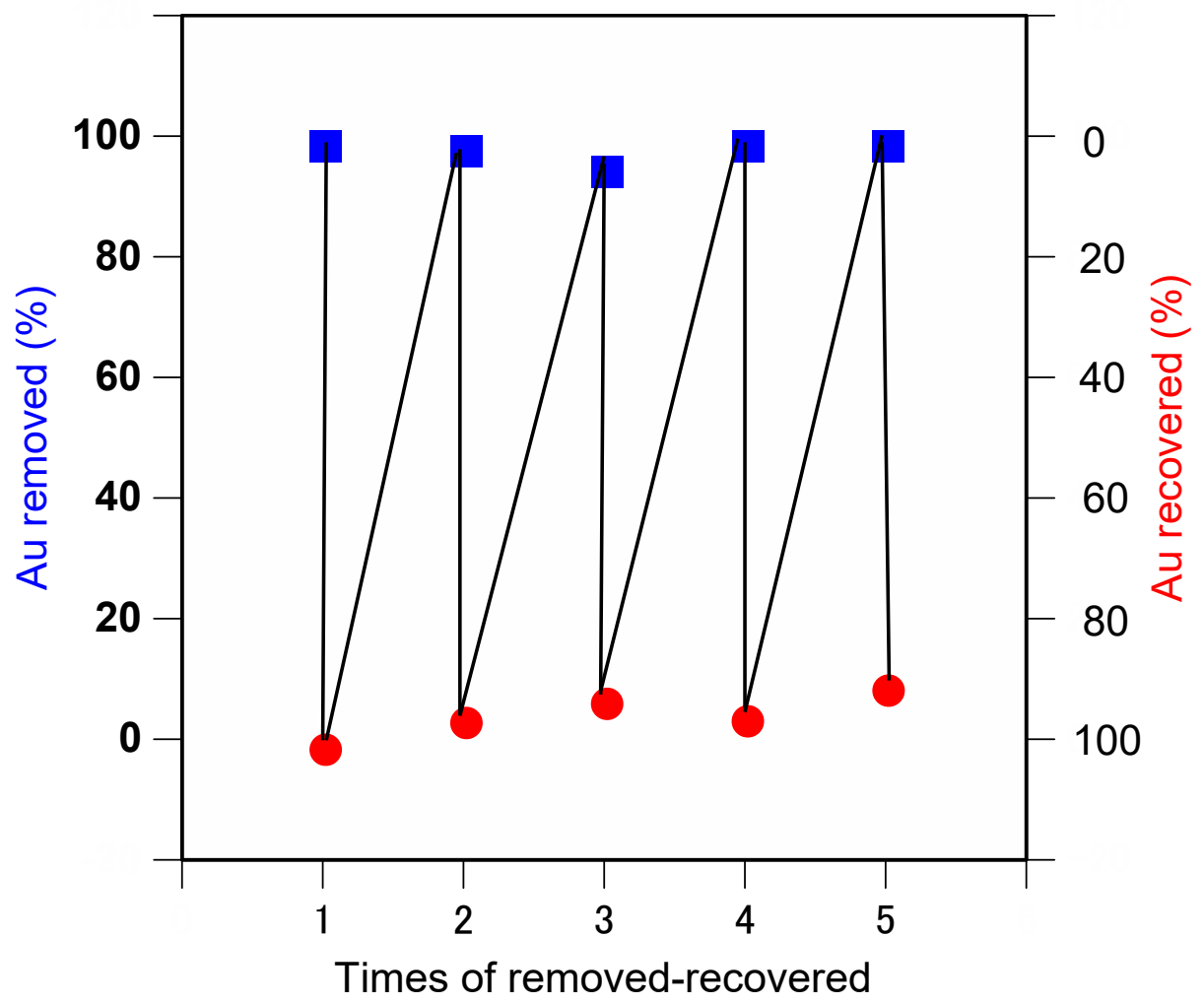

Figure 9. Recycles gold removal (72h at the first time and $1 \mathrm{~h}$ after second time) and recovery of gold (1 h) by immobilized $P$. saccharophila cells

\section{Conclusions}

To optimize gold recovery, we examined some factors affected on gold removal from aqueous hydrogen tetrachloroaurate solution using $P$. saccharophila cells by biomineralization.

The effects of incubation time, $\mathrm{pH}$, cell amount, and initial gold concentration on gold removal were analyzed by atomic absorption spectrometry. We observed that about half the amount of gold(III) was removed from the solution by biosorption after a short incubation time (1h) and the remaining half was reduced from gold(III) to gold (0) by biomineralization on the cell surface by $P$. saccharophila cells after 72-hour incubation.

Gold (III) can be removed using $P$. saccharophila cells by biomineralization effectively. Therefore, the recycles of removal of gold (III) for $72 \mathrm{~h}$ from gold (III) solution (Au $50 \mathrm{mg} / \mathrm{L}$ ) using immobilized $P$. saccharophila cells and recovery of removed reduced gold for $17 \mathrm{~h}$ using $0.25 \mathrm{M}$-thiourea solution was examined 5 times. Most of the gold (III) can be removed and recovered in these cycles. At the first time of removal, gold (III) was reduced slowly and cells became violet color. When recovery of gold was started, the color was rapidly vanished 
within $1 \mathrm{~h}$. At the second cycle of removal, immobilized cells became bright rapidly. Therefore, time course of gold recovery and second cycle of gold removal was examined. Both of oxidative gold recovery and second time reductive gold removal $t$ were proceeded rapidly. Therefore, recycles of removal ( $72 \mathrm{~h}$ for the first time)-recovery (1h)-removal ( $1 \mathrm{~h}$ for after the second time) cycles can be carried out in this system. At the first time of removal, gold (III) was reduced slowly and cells became violet color. When recovery of gold was started, the color was rapidly vanished within $1 \mathrm{~h}$. At the second cycle of removal, immobilized cells became more deep gold color rapidly. Therefore, time course of gold recovery and second cycle of gold removal was examined. Both of gold recovery and second time removal of that were proceeded rapidly. Recycles of removal ( $72 \mathrm{~h}$ for the first time)-recovery (1h)-removal ( $1 \mathrm{~h}$ for after the second time) cycles can be carried out in this system.

\section{References}

[1] Suhr, M., Raff and J., Pollmann, K, “Au-Interaction of Slp1 Polymers and Monolayer from Lysinibacillus sphaericus JG-B53-QCM-D, ICP-MS and AFM as Tools for Biomolecule-metal Studies," J. Vis. Exp., 107. e53572. 2016.

[2] Paez-Velez, C., Rivas, R.E., and Dussan, J, "Enhanced Gold Biosorption of Lysinibacillus sphaericus CBAM5 by Encapsulation of Bacteria in an Alginate Matrix," Metals, 9. 818-827. 2019.

[3] Gomes, N.C.M., Camargos, E.R.S., Dias, J.C.T., and Linardi, V.R, "Gold and Silver Accumulation by Aspergillus niger from Cyanide-containing Solution Obtained from the Gold Mining Industry," World J. Microbiol. Biotechnol., 14. 149. 1998.

[4] Matsumoto, M. and Nishimura, Y, "Recovery by Aspergillus oryzae of Gold from Waste Water from Gold Plating," Nippon Nougeikagakukaishi, 66. 1765-1770. 1992 (in Japanese).

[5] Pethkar, A.V. and Paknikar, K.M, "Recovery of Gold from Solutions Using Cladsporium cladosporioides Biomass Beads," J. Biotechnol., 63. 121-136. 1998.

[6] Karamuchka, V. and Gadd, G.M, "Interaction of Saccharomyces cerevisiae with Gold: Toxicity and Accumulation," BioMetals, 12. 289-294. 1999.

[7] Hosea, M., Greene, B., McPherson, R., Henzl, M., Alexander, M.D., and Darnall, D.W, "Accumulation of Elemental Gold on the Aalga Chlorella vulgaris," Inorg. Chim. Acta, 123. 161-165. 1986. 
[8] Kuyucak, N., and Volesky, B, “Accumulation of Gold by Algal Biosorbent," Biorecovery, 1. 189-204. 1989.

[9] Tsuruta, T, "Biosorption and Recycling of Gold Using Various Microorganisms," J. Gen. Appl. Microbiol., 50. 221-228. 2004.

[10] Tsuruta, T, "Removal and Recovery of Lithium Using Various Microorganisms," $J$. Biosci. Bioeng., 100. 562-566. 2005.

[11] Tsuruta, T., Umenai, D., Hatano, T., Hirajima, T., and Sasaki, K, "Screening Microorganisms for Cadmium Absorption from Aqueous Solution and Cadmium Absorption Properties of Arthrobacter nicotianae," Biosci. Biotechnol. Biochem., 78. 1791-1796. 2014.

[12] Tsuruta, T, "Removal and Recovery of Uranyl Ion Using Various Microorganisms," J. Biosci. Bioeng., 94. 23-28. 2002.

[13] Tsuruta, T,. "Accumulation of Thorium Ion Using Various Microorganisms," J. Gen. Appl. Microbiol., 49. 215-218. 2003.

[14] Tsuruta, T, “Accumulation of Rare Earth Elements in Various Microorganisms," J. Rare Earths, 25. 526-532. 2007.

[15] Conn, E.E., Stumpf, P.K., Bruening, G., and Doi, R. H, Outlines of Biochemistry, 5th ed., Wiley, New York, U. S. A., 292-293. 1987.

[16] Fischer, W., Ishizuka, I., Landgraf, H.R., and Herrmann, J, “Glycerophosphoryl Diglucosyl Diglyceride, A New Phosphoglycolipid from Streptococcus, Biochim. Biophys. Acta, 296. 527-545. 1973a.

[17] Fischer, W., Landgraf, H.R., and Herrmann, J, "Phosphatidyldiglucosyl Diglyceride from Streptococci and Its Relationship to Other Polar Lipids," Biochim. Biophys. Acta, 306. 353-367. 1973b.

[18] Paul, R.J. and Schneckenburger, H, "Oxygen Concentration and the Oxidation-reduction State of Yeast: Determination of Free/Bound NADH and Flavins by Time-Resolved Spectroscopy," Sci. Nat., 83. 32-35. 1996.

[19] Maeda, I. and Tsuruta, T, "Microbial Gold Biosorption and Biomineralization from Aqueous HAuCl4 Solution,” Minerals, 10. 285-293. 2020.

[20] Doremus, R. H, “Optical Properties of Small Gold Particles," J. Chem. Phys., 40. 23892396. 1964. 